\title{
THE NATURE CONSERVANCY OF CANADA
}

\section{by George F. Ledingham, Regina}

For several years a group of active naturalists in the Toronto area have been planning the formation of The Nature Conservancy of Canada. All legal steps have now been completed and this Corporation is ready to go to work and fulfill some of its aims.

On February 16, 1965, the first annual meeting of the members and trustees of the Nature Conservancy of Canada was held in Toronto in the office of $\mathrm{Mr}$. Bill Harris, 55 Yonge Street. As the trustee for Saskatchewan and as a representative of the Saskatchewan Natural History Society, it was my duty and pleasure to attend this meeting. We approved developments to date and discussed the future plans of the organization. The other trustees present were W. W. H. (Bill) Gunn, F. Aird Lewis, William B. Harris, Antoon de Vos, Charles D. Fowle and John A. Livingston from Ontario; Roderick Haig-Brown from British Columbia; the Honourable George $H$. Montgomery from Quebec and William A. Fuller from Alberta. Other names will soon be added to this list.

According to its Charter, the Conservancy may work for a better understanding of conservation among Canadians, and may establish, maintain, develop and manage nature reserves. To carry out these objectives, it may solicit donations, bequests, or subscriptions of money or other real or personal property. It may purchase or lease lands and enter into agreements with authorities, public or academic, in achieving its objectives. Money collected may be invested if not immediately needed to achieve the objectives of the Corporation, but the business of the Corporation shall be carried out without pecuniary gain to its members and all profits shall be used in promoting its abjectives.

The organization of this Corporation reflects the feeling of many Canadians that there ought to be some way in which we can guarantee the preservation of areas of intrinsic value. Owners of land who are concerned about the future of property after their death may discuss their wishes with the Nature Conservancy. If their wishes are in keeping with the aims of the Nature Conservancy then it is possible that the property can be left to the care of this national group of people interested in the conservation and use of natural sites. The use of these sites will vary widely depending on the particular features included within each area. In some areas maximum use by interested public will be encouraged but in other areas it is likely that strict protection will be needed to achieve the aims of the project.

In most cases the Nature Conservancy of Canada will provide the machinery and the money for the purchase of property which will then be used in keeping with the aims of the Corporation. Public spirited Canadians who are interested can help in two ways. First, of course, they can donate money and there will always be a need for funds, especially now to get this worthy cause started in Canada. Money can be donated for specific projects as they are described and special pleas are made for them or money can just be donated to be used as the Corporation sees fit. Second, you can help with suggestions for projects.

In Saskatchewan several conservation projects have been discussed and you may have read of some of these in the Blue Jay. On February 19, when Bill Gunn was in Regina, a group of enthusiastic people with rather widely different interests met to discuss projects for Saskatchewan. The project meeting with most favor was one involving protection of resting areas for the Sandhill Crane but no special committee for this project has, as yet, been organized. Saskatoon naturalists have discussed other projects.

There is need for active development of projects and all of these will need money. I hope you will soon be able to read of specific projects in our SNHS Newsletter, but in the meantime donations and inquiries may be sent to me c/o Box 1121, Regina, or to Mr. F. Aird Lewis, 172 Forest Hill Road, Toronto 7, Ontario. 